Article

\title{
Efficient Low-Cost Anaerobic Treatment of Wastewater Using Biochar and Woodchip Filters
}

\author{
Korbinian Kaetzl * (1), Manfred Lübken, Tito Gehring ${ }^{(0)}$ and Marc Wichern \\ Institute of Urban Water Management and Environmental Engineering, Ruhr-Universität Bochum, \\ Universitätsstraße 150, 44780 Bochum, Germany; manfred.luebken@rub.de (M.L.); tito.gehring@rub.de (T.G.); \\ marc.wichern@rub.de (M.W.) \\ * Correspondence: korbinian.kaetzl@rub.de; Tel.: +49-234-322-6105
}

Received: 6 June 2018; Accepted: 19 June 2018; Published: 21 June 2018

\begin{abstract}
Access to improved sanitation is often lacking in many low-income countries, and approximately $90 \%$ of the sewage is discharged without treatment into receiving water bodies. The aim of this study was the development and evaluation of an efficient low-cost wastewater treatment system for developing countries. Biochar and woodchips, potential locally available and inexpensive materials, were used for anaerobic wastewater filtration and their suitability evaluated in comparison to gravel as a common reference material. Filters were fed with raw sewage from a municipal full-scale wastewater treatment plant in Germany at $22{ }^{\circ} \mathrm{C}$ room temperature with a hydraulic loading rate (HLR) of $0.05 \mathrm{~m} \cdot \mathrm{h}^{-1}$. This resulted in a mean organic loading rate (OLR) of $252 \mathrm{~g}_{\mathrm{COD}} \cdot \mathrm{m}^{-3} \cdot \mathrm{d}^{-1}$ and a mean organic surface load of $456 \mathrm{~g} \mathrm{COD} \cdot \mathrm{m}^{-2} \cdot \mathrm{d}^{-1}$. To determine the influence of different filter materials, the removal efficiency of chemical oxygen demand (COD), total organic carbon (TOC), turbidity, and faecal indicator bacteria (FIB) E. coli and enterococci were tested. It was found that COD (up to $90 \%$ ), TOC (up to $80 \%$ ), FIB (up to $1.7 \log _{10}$-units), and turbidity (effluent turbidity below $35 \mathrm{NTU}$ ) could be significantly reduced. The findings of this study demonstrate the potential of anaerobic filters (AFs) for wastewater treatment in low-income countries to reduce water pollution and comprehensively improve water quality. The performance of biochar filters was significantly better over the entire experiment compared to woodchip and gravel filters with respect to COD, TOC, turbidity, and FIB removal, indicating the superior properties of biochar for wastewater treatment.
\end{abstract}

Keywords: biochar; anaerobic filter; anaerobic wastewater treatment; decentralised treatment; low-cost sewage treatment; developing countries; COD; UV absorbance

\section{Introduction}

Insufficient access to sanitation and clean water is one of the most prevalent problems affecting people worldwide [1]. Due to global population and economic growth, rapid urbanization, and climate change, water scarcity is expected to increase in coming decades, particularly within developing countries [2,3]. The situation is dramatically aggravated by the fact that approximately 2.4 billion people still do not have access to improved sanitation, and approximately $90 \%$ of the sewage in low-income countries is discharged without treatment into surface waters [4,5]. Irrigation accounts for roughly $90 \%$ of total water consumption in many rapidly developing economies [6], and is seriously compromised by the contamination of water bodies, which leads to widespread diseases in agriculture products. Hence, there is urgent demand for the development and implementation of low-cost, simple, compact, and efficient wastewater treatment systems for a sustainable reduction of water pollution.

Anaerobic filters (AFs) were first described in 1969 by Young and McCarty [7], and gained importance as a technology for treating diverse industrial wastewaters [8]. However, to our knowledge, 
less research has been conducted concerning the anaerobic filtration of domestic wastewater. According to the literature (Table A1), a chemical oxygen demand (COD) reduction of up to $90 \%$ could be achieved by treating domestic sewage with AF $[9,10]$. Assuming a hydraulic loading rate (HLR) of $0.05 \mathrm{~m}^{3} \cdot \mathrm{m}^{-2} \cdot \mathrm{h}^{-1}$ (which was used in the experiments here), AF requires notably less space than pond systems or constructed wetlands [11] to achieve similar removal rates of chemical oxygen demand (COD). This makes AF attractive for urban areas with restricted available space. In contrast to upflow anaerobic sludge blanket (UASB) reactors, the construction, maintenance, and operation of AF is much simpler, requiring only a tank and filling material. Moreover, different from trickling filters or constructed wetlands, a thorough pre-treatment of raw sewage is not necessary. In the case of clogging, AF can be easily backflushed. The physical filtration effect of filling materials in AF makes a washout of sludge and particulate matter difficult, and improves effluent water quality [12]. With a removal rate of faecal indicator bacteria (FIB) of approximately $90 \%$ (or $1 \log _{10}$-unit), AFs also eliminate a substantial amount of pathogens and contribute to a safer water quality [13,14]. High removal efficiency of suspended solids (SS) $[9,13,15]$ and turbidity [16] allows a further purification of filter effluent.

Rocks or plastic support materials are commonly used as filter materials for AF (Table A1). These materials might be impediments for the adoption of AF on a widespread scale in some low-income countries due to high transportation or manufacturing costs [17]. Hence, alternative low-cost filter materials with suitable properties, high specific surface area, low bulk densities, and local availability might be attractive filling materials for AF. The applicability of different low-cost filling materials for AF has been evaluated in several studies. AF with coconut shells achieved a mean COD reduction of $65-73 \%$ in treating domestic wastewater [12,15]. With bamboo rings, an average COD elimination between $60 \%$ and $80 \%$ could be obtained [18], while waste tyre AF removed on average $60 \%$ of the COD from domestic wastewater. A study with an aerobic biofilter system used agave fibre as filter material and removed $62-80 \%$ COD from pre-settled domestic wastewater [19].

Prior investigations suggest woodchips and biochar as suitable for wastewater treatment. In a study with woodchips as filter material for AF-a mean biological oxygen demand (BOD) elimination of $78 \%$ to $83 \%$ was reported [20]. In studies with aerobic biofilter systems for municipal sewage treatment, a mean COD reduction of 71\% [21] and 78\% [22] could be achieved using woodchips as filter materials. Ahsan et al. obtained a COD reduction of up to $88 \%$ by treating domestic wastewater with biochar as filtration media [23]. In column experiments with biochar as packing material and intermittent inflow of municipal raw sewage, an average COD reduction of $95 \%$ could be achieved [24]. In a previous study, we found an average COD reduction of $73 \%$ for biochar columns when treating pre-settled raw wastewater with an anaerobic biofilter, which was significantly better than sand columns (58\%) [25]. In experiments with vertical constructed wetlands treating synthetic wastewater, biochar-amended wetlands removed significantly more COD (up to $85 \%$ ) than without biochar (up to $68 \%$ ) [26]. Due to its porous structure and high specific surface area $[27,28]$, biochar might also act as a low-cost sorbent potentially removing emergent contaminants $[29,30]$. Still, biochar and woodchips were not thoroughly evaluated as filling material for domestic wastewater treatment with AF (Table A1).

One remarkable advantage of biochar and woodchips is their capability of closing loops, since both materials could further be used for combustion and energy production, or in the case of woodchips as feedstock for biochar production [31]. Additionally, biochar can be produced locally from (waste) biomass or agricultural residues [29,32,33], and might be used as soil amelioration after wastewater treatment [34].

The main goals of this study were the investigation of biochar and woodchips as alternative filter materials to gravel for the filtration of pre-settled raw wastewater under anaerobic conditions. For that purpose, the focus of the experiment was on (1) the reduction of chemical oxygen demand (COD) and total organic carbon (TOC) and (2) turbidity removal of raw sewage as a parameter for total suspended solids (TSS), to estimate the suitability of AF as a potential pre-treatment for further water purification with slow sand or bio-filters. Additionally, (3) the capability of these filter materials to eliminate FIB as 
a contributing factor to safer irrigation water production was evaluated, and (4) correlation analysis of ultraviolet (UV) absorbance and COD concentration was conducted to allow for a rapid analysis of organic matter removal efficiency.

\section{Materials and Methods}

\subsection{Filter Materials}

Three different filter materials were studied in this experiment. Gravel is a common filter material for anaerobic filtration, and was used as a reference material. Quartz gravel was obtained from Quarzwerke GmbH (Bottrop-Kirchhellen, Germany) in three different size fractions: 11-16 mm, 8-11 mm, and 5-8 mm. A commercial biochar (Schottdorf GmbH, Wallerstein, Germany) was chosen for this experiment for reproducibility purposes, but biochar can be produced locally through simple methods, as discussed elsewhere [33]. Biochar was produced by a large-scale gasifier at a temperature of approximately $700{ }^{\circ} \mathrm{C}$ out of different soft woods with unknown composition. In the woodchip filters, commercial spruce woodchips (Kompostwerke Olpe, Olpe, Germany) were used. Biochar and woodchips were sieved through 5,8,11, and $16 \mathrm{~mm}$ screens to obtain similar grain fractions to those of gravel. Before using, all materials were washed with tap water to remove fine particles.

Filter materials were characterized with respect to chemical composition, specific surface area, and surface charge. For that, an elementary analysis of biochar and woodchips were conducted according to DIN 51732 and DIN EN 14582, while the composition of quartz gravel was obtained from Quarzwerke $\mathrm{GmbH}$ (Bottrop-Kirchhellen, Germany). It is expected that physical and chemical properties, such as the carbon $(\mathrm{C})$, oxygen $(\mathrm{O})$, hydrogen $(\mathrm{H})$, and nitrogen $(\mathrm{N})$ contents and ratios, have a strong influence on adsorption behaviour [35]. Detailed information about the elemental composition of the biochar and woodchips is provided in the supplementary materials (Tables S1 and S2).

Another parameter that can be used to estimate the sorption characteristics of a collector is the surface charge. Zeta potential (ZP), which is related to particle surface charge [36], was measured with a Malvern Zetasizer Nano ZS (Malvern, Herrenberg, Germany) at a pH of 6.0 for all three filter materials. For that, all materials were ground to powder and the ZP of these particles was subsequently measured (Tables S1 and S2).

To determine the surface area of biochar and woodchips, a BET (Brunner Emmet Teller) multipoint adsorption isotherm with $\mathrm{N}_{2}$ as adsorbent was prepared in a surface analyser at $77 \mathrm{~K}$ (Autosorb 6, Quantachrome Instruments, Boynton Beach, FL, USA) according to DIN ISO 9277. The surface area of quartz gravel was calculated according to Wichern et al. [37]. The mean ZP of gravel was $-28.4 \pm 1.3 \mathrm{mV}$ (variation range indicates standard deviation)—slightly more negative than that of biochar $(-20.8 \pm 0.8 \mathrm{mV})$ and woodchips $(-13.1 \pm 1.6 \mathrm{mV})$. As expected, the specific surface area of biochar $\left(1.11 \times 10^{8} \mathrm{~m}^{2} \cdot \mathrm{m}^{-3}\right)$ was significantly higher than that of woodchips $\left(1.69 \times 10^{5} \mathrm{~m}^{2} \cdot \mathrm{m}^{-3}\right)$ and gravel $\left(<1.55 \times 10^{3} \mathrm{~m}^{2} \cdot \mathrm{m}^{-3}\right)$ (compare Table S1). Finally, scanning electron images of material surfaces were taken with an LEO (Zeiss) 1530 Gemini field emission scanning electron microscope (FESEM; Zeiss, Oberkochen, Germany) for comparison of surface structure and porosity (Figure 1).

\subsection{Filter Design and Experimental Setup}

The experimental setup consisted of nine glass filter columns with an inner diameter of $5 \mathrm{~cm}$ and a total height of $180 \mathrm{~cm}$ each. Filters were designed as vertical upflow AF with three layers and were covered with aluminium foil to prevent algal growth.

A $10-\mathrm{cm}$ layer of gravel, with a grain size of $11-16 \mathrm{~mm}$, was located at the bottom to achieve uniform inlet conditions for all nine filters. Subsequently, three 50-cm layers of the same filter material with decreasing grain sizes were added. In order to prevent floating of the light woodchips and biochar, another $10-\mathrm{cm}$ gravel layer with a particle size of $5-8 \mathrm{~mm}$ was added to all nine filters, followed by a 10-cm supernatant water layer (Figure 1). 

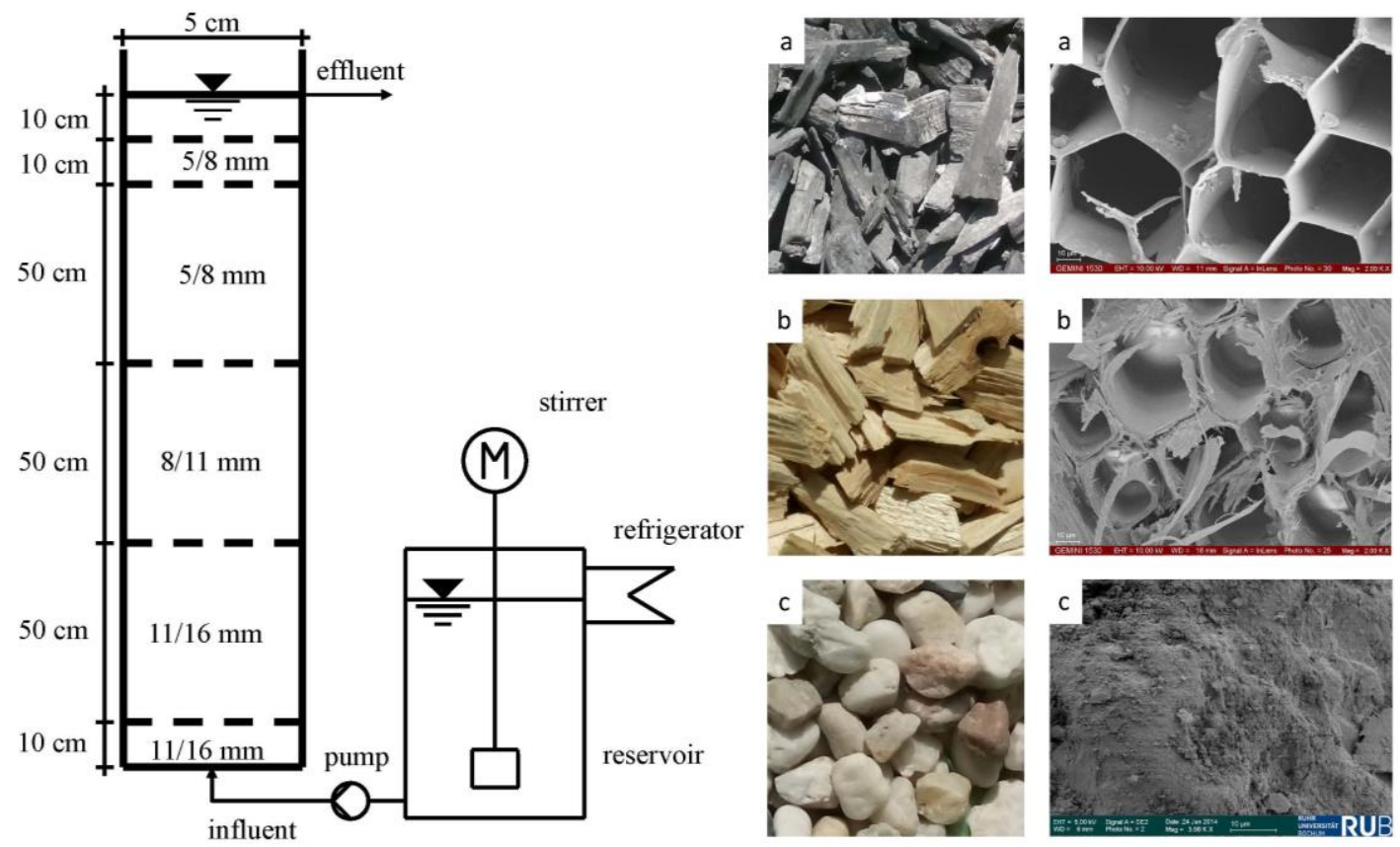

Figure 1. Schematic drawing of experimental setup. Pictures and scanning electron microscope (SEM) images from used (a) biochar, (b) woodchips, and (c) gravel.

\subsection{Operating Parameters}

Initially, the filters were operated with tap water with a hydraulic loading rate (HLR) of $0.05 \mathrm{~m} \cdot \mathrm{h}^{-1}$ for two weeks after their first filling. During this time, tracer experiments with sodium chloride $(\mathrm{NaCl})$ were conducted to determine the hydraulic retention time (see description below). Subsequently, the filters were operated with municipal wastewater from the full-scale treatment plant Ölbachtal (Ruhrverband, Bochum, Germany). The effluent from the grit chamber was taken and sieved over a 200 $\mu \mathrm{m}$ curved screen to separate particles and simulate a primary clarifier. This pre-treated wastewater was stored in an opaque barrel, protected from light, and cooled to $4-6{ }^{\circ} \mathrm{C}$ (Lauda, Lauda-Königshofen, Germany) to prevent die-off of FIB and biological degradation during storage time. The storage reservoir was continuously stirred to avoid sedimentation. The wastewater reservoir was renewed two times per week. The filters were fed by peristaltic pumps (Watson Marlow 205S and Watson Marlow $323 S$ (Falmouth, United Kingdom)) with a constant HLR of $0.05 \mathrm{~m} \cdot \mathrm{h}^{-1}$. The HLR was controlled every day, and inlet and outlet tubes were flushed with sodium hypochlorite every week to prevent clogging due to biofilm growth. The HLR was calculated by the volumetric flow rate per hour and cross-sectional filter area. The experiment was conducted at a constant room temperature of $22 \pm 1^{\circ} \mathrm{C}$. The mean organic surface load was $19 \mathrm{gCOD} \cdot \mathrm{m}^{-2} \cdot \mathrm{h}^{-1}$ (standard deviation (SD): 6.1, $n=6$ ) and $7 \mathrm{~g}$ TOC $\cdot \mathrm{m}^{-2} \cdot \mathrm{h}^{-1}$ (SD: $2.3, n=6)$, respectively. This resulted in a mean organic loading rate (OLR) of $252 \mathrm{gCOD} \cdot \mathrm{m}^{-3} \cdot \mathrm{d}^{-1}$ (SD: $81, n=6)$ and $93 \mathrm{~g}_{\mathrm{TOC}} \cdot \mathrm{m}^{-3} \cdot \mathrm{d}^{-1}(\mathrm{SD}: 31, n=6)$. The high standard deviation was a result of natural fluctuations of the raw municipal wastewater composition, as detailed in Table 1.

Table 1. Average characteristics of the raw domestic sewage used as influent in the filtration experiment. E. coli and enterococci concentration are given as most probable number (MPN). Variation ranges indicate the standard deviations $(n=6)$.

\begin{tabular}{ccc}
\hline Parameter & Unit & \\
\hline Chemical oxygen demand (COD) & $\mathrm{mg} \cdot \mathrm{L}^{-1}$ & $372 \pm 120$ \\
Total organic carbon (TOC) & $\mathrm{mg} \cdot \mathrm{L}^{-1}$ & $137 \pm 45$ \\
Total nitrogen $\left(\mathrm{N}_{\text {tot }}\right)$ & $\mathrm{mg} \cdot \mathrm{L}^{-1}$ & $70 \pm 12.4$ \\
\hline
\end{tabular}


Table 1. Cont.

\begin{tabular}{ccc}
\hline Parameter & Unit & \\
\hline Total phosphorous $\left(\mathrm{P}_{\text {tot }}\right)$ & $\mathrm{mg} \cdot \mathrm{L}^{-1}$ & $2.6 \pm 0.5$ \\
$\mathrm{pH}$ & & $7.8 \pm 0.2$ \\
Electrical conductivity $(\mathrm{EC})$ & $\mu \mathrm{S} \cdot \mathrm{cm}^{-1}$ & $1178 \pm 166$ \\
Turbidity & $\mathrm{FNU}$ & $260 \pm 92$ \\
E. coli & $\log _{10} \mathrm{MPN} \cdot \mathrm{mL}^{-1}$ & $4.93 \pm 0.39$ \\
Enterococci & $\log _{10} \mathrm{MPN} \cdot \mathrm{mL}^{-1}$ & $4.29 \pm 0.28$ \\
\hline
\end{tabular}

\subsection{Porosity and Hydraulic Retention Time}

The porosity of filter materials was determined using a defined volume of dried (at $105{ }^{\circ} \mathrm{C}$ ) samples, which were transferred into a graduated cylinder with a diameter of $5 \mathrm{~cm}$ that was weighted before and after filling. The cylinder was gently shaken to achieve equal bulk density as in the filter columns and then filled with distilled water. Subsequently, the cylinder was gently heated and boiled to remove air bubbles. The supernatant water was removed, and the volume and weight of the saturated material was measured again. Due to the porous structure of biochar and woodchips, the porosity was determined twice: first with dried materials to estimate the total porosity, and subsequently with water-saturated materials for the effective porosity of the filter bed.

Tracer experiments also allowed a more detailed insight in flow conditions within the columns. For that, a 15-mL solution of tap water and $3 \mathrm{~g}$ sodium chloride was added as a pulse tracer. Subsequently, the electrical conductivity (EC) of the effluent was monitored as a function of time [38] with a sampling interval of one minute, and shortest, longest, and mean residence times in the columns were determined. The shortest residence time was defined as the time between adding the sodium chloride and the rise of the EC in the filter effluent. The longest retention time was determined as the time when the EC reached the background conductivity again. Mean residence time was calculated as the time when $50 \%$ of the total tracer recovery was eluted [39].

\subsection{Sampling}

Sampling of filter influent and effluent was carried out every week. In order to compensate the filter hydraulic retention time, the influent was always sampled four days before the filter effluents. Filters were operated with wastewater for 6 days to flush out the tap water before the first sampling occurred. At each sampling, the following samples were manually taken: $\sim 45 \mathrm{~mL}$ for Escherichia coli (E. coli) and intestinal enterococci enumeration (50-mL sterilized centrifuge tubes) and $200 \mathrm{~mL}$ for COD, TOC, total nitrogen $\left(\mathrm{N}_{\mathrm{ott}}\right)$, and total phosphorous $\left(\mathrm{P}_{\text {itot }}\right)$ analysis $(250 \mathrm{~mL}$ polypropylene $(\mathrm{PP})$ bottles). Samples for microbiological analyses were refrigerated at $4{ }^{\circ} \mathrm{C}$ and analysed within $24 \mathrm{~h}$. After collection, samples for chemical analyses were stored at $-20{ }^{\circ} \mathrm{C}$ until analysis. Ancillary data were also collected at each sampling interval, including $\mathrm{pH}$, water temperature $(\mathrm{T}), \mathrm{EC}$, redox potential, turbidity, and UV extinction (190-254 nm).

\subsection{Physico-Chemical Parameters}

Due to the very low concentration of total suspended solids (TSS) in filter effluent, it was not possible to adequately measure this parameter (Figure S3). Thus, turbidity was chosen instead of TSS for estimation of filter performance with respect to the removal of suspended solids. Turbidity was measured according to DIN ISO 7027 with a Hach turbidimeter 2100P ISO (Lange, Düsseldorf, Germany). COD concentrations were determined through cuvette tests (Lange, Düsseldorf, Germany). TOC analyses were carried out with a DIMATOC 2000 (Dimatec Analysetechnik GmbH, Essen, Germany). Wet-chemical analysis was used to determine $\mathrm{N}_{\text {tot }}$ and $\mathrm{P}_{\text {tot }}$ concentrations in the water, according to DIN 38409-28 and DIN EN ISO 6878, respectively. A Multi 3430 (WTW, Weilheim, Germany) was used for electrochemical analyses ( $\mathrm{pH}, \mathrm{T}, \mathrm{EC}$, and redox potential). 
UV extinction between 190 and $254 \mathrm{~nm}$ was determined using a Spectronic Helios Alpha spectrophotometer (Thermo Scientific, Waltham, MA, USA) photometer. The samples were filtered with a $0.45-\mu \mathrm{m}$ carbon free membrane filter (VWR, Radnor, PA, USA) and transferred into a quartz glass cuvette with $1 \mathrm{~cm}$ width. Distilled water was used as blank to subtract the autofluorescence of the water.

\subsection{Microbiological Analyses}

E.coli and enterococci were quantified using the standardized microplate methods for wastewater DIN EN ISO 9308-3 and DIN EN ISO 7899-1, respectively (Bio-Rad, Munich, Germany). The detection of enterococci is based on the presence of the enzyme beta-glucoside. When present in a sample exposed to the rehydrated substrate 4-methyl-umbelliferyl-beta-D-glucoside (MUD), a fluorescent compound detectable with ultraviolet light $(\lambda=360 \mathrm{~nm})$ is released. Microplates for E. coli quantification contained the dehydrated substrate 4-methyl-umbelliferyl-beta-D-glucuronide (MUG) which reacts in a similar fashion, however with the enzyme beta-glucuronidase. The microplates were incubated for 36 to $72 \mathrm{~h}$ and subsequently read manually. The method detection limit is $0.56 \mathrm{MPN} \cdot \mathrm{mL}^{-1}$ (MPN: most probable number).

\subsection{Data Analysis}

Statistical analyses were performed with OriginPro 2016 (Northampton, MA, USA). Data sets were tested for normal distribution with Shapiro-Wilk test by using a level of significance of $p<0.05$. Normally distributed data were analysed for significance by analysis of variance (ANOVA) and the Tukey test $(p<0.05)$ was used for post-hoc comparison. Since measured values of turbidity were non-normally distributed, the Mann-Whitney test was used as a non-parametric test. Outliers in the dataset were identified and excluded with a Grubbs' test, while box plots were used for the identification of highly unlikely data, and values were checked for plausibility.

\section{Results and Discussion}

\subsection{Porosity and Hydraulic Retention Time}

The measurement of hydraulic residence time and tracer recovery provides important information, as they affect the contact time of the wastewater with the filter material as well as with the biofilm that develops on its surface. Longer residence times allow for a more efficient biodegradation of organic matter and pathogens [40]. The theoretical hydraulic retention times (HRTs) in the columns were calculated by the porosity and HLR (Table S3) and compared with $\mathrm{NaCl}$ tracer tests (Figure S1). Additionally, the void volume and void ratio of filters were determined using the water-saturated porosity of the filter materials. There was a notably shorter calculated HRT for biochar and woodchips, compared to tracer results (Table 2).

During the four days of monitoring tracer in the effluent, more than $95 \%$ of the $\mathrm{NaCl}$ was recovered from the gravel, woodchips, and biochar filters. The high tracer recovery in all three filter materials was unexpected, and was in contrast to other published results where recovery rate was notably lower, especially for biochar filters [39]. The high specific surface area of biochar was expected to result in the adsorption of ions.

Obviously, the earlier and sharper conductivity breakthrough of gravel filters resulted in a shorter mean residence time. This indicates a homogenous packed filter bed with a lower porosity, while woodchips and biochar filters seemed to have a more heterogeneous packed filter bed with a higher immobile water fraction. This can be explained by the pin-shaped and uneven structure of these materials, which resulted in a longer tracer residence time and a lower tracer peak. Higher porosity and diffusion of water and tracer or contaminants from the mobile to the immobile water fraction and subsequently dilution in immobile water increases the HRT and consequently decreases the effective flow velocity. 
Table 2. Hydraulic characteristics of the different filter materials. The porosities of water-saturated biochar and woodchips were used to calculate the theoretical hydraulic retention times (HRTs). HRTs were calculated from the storage reservoir to effluent sampling, including water residence time in tubes.

\begin{tabular}{cccccccc}
\hline Filter Material & $\begin{array}{c}\text { Shortest Residence Time } \\
\text { (h) }\end{array}$ & $\begin{array}{c}\text { Tracer Peak } \\
\text { (h) }\end{array}$ & $\begin{array}{c}\text { Mean Residence Time } \\
\text { (h) }\end{array}$ & $\begin{array}{c}\text { Longest Residence Time } \\
\text { (h) }\end{array}$ & $\begin{array}{c}\text { Theoretical HRT } \\
\text { (h) }\end{array}$ & $\begin{array}{c}\text { Void Volume } \\
\text { (L) }\end{array}$ & $\begin{array}{c}\text { Void Ratio } \\
(-)\end{array}$ \\
\hline Gravel & 11.8 & 13.5 & 21.2 & 73.5 & 17.2 & 1.6 & 0.45 \\
Woodchips & 17.3 & 23 & 33.7 & 79.4 & 20.5 & 1.91 \\
Biochar & 16.1 & 22.9 & 34.5 & 99.5 & 0.54 & 17.8 & 1.66 \\
\hline
\end{tabular}

\subsection{Removal of Chemical Parameters by Different Filter Materials}

Overall, biochar filters removed significantly (ANOVA, $p<0.05$ ) more COD and TOC than other materials (Table 3). No significant difference in removal rates of TOC could be observed for woodchip and gravel filters, while gravel removed substantially more COD than woodchips. Higher COD and TOC removal rates of biochar filters were also reported by Ahsan et al. [23] and were determined in previous studies [25]. The superior performance of biochar columns might be explained by their higher adsorption capacity $[23,27]$. The possible effect due to the slightly longer HRTs for biochar and woodchip columns with respect to COD and TOC removal should be very low [14]. Achieved COD removal rates were in the same range or higher than other published results (Table A1). A long start-up phase to reach steady state conditions (as recommended in some studies [14,41]) was not necessary in this experiment, in agreement with Young and McCarty (1969) [7].

Table 3. Mean effluent concentration and removal rates of different filter materials over experimental time. Different letters $\left({ }^{a}, b, c\right)$ indicate a significant difference of the mean (ANOVA, $p<0.05$ ) between materials after post hoc analysis. Standard deviations are presented as variation range.

\begin{tabular}{|c|c|c|c|c|c|c|}
\hline \multirow[t]{2}{*}{ Parameter } & \multicolumn{2}{|c|}{ Woodchips } & \multicolumn{2}{|c|}{ Biochar } & \multicolumn{2}{|c|}{ Gravel } \\
\hline & Concentration & Removal & Concentration & Removal & Concentration & Removal \\
\hline & $\begin{array}{c}1\left(\mathrm{mg} \cdot \mathrm{L}^{-1}\right) \\
{ }^{2}\left(\log _{10} \mathrm{MPN} \cdot \mathrm{mL}^{-1}\right)\end{array}$ & $\begin{array}{c}1(\%) \\
{ }^{2}\left(\log _{10} \mathrm{MPN} \cdot \mathrm{mL}^{-1}\right)\end{array}$ & $\begin{array}{c}\left.1 \text { (mg. } \mathrm{L}^{-1}\right) \\
{ }^{2}\left(\log _{10} \mathrm{MPN} \cdot \mathrm{mL}^{-1}\right)\end{array}$ & $\begin{array}{c}1(\%) \\
{ }^{2}\left(\log _{10} \mathrm{MPN} \cdot \mathrm{mL}^{-1}\right)\end{array}$ & $\begin{array}{c}1\left(\mathrm{mg} \cdot \mathrm{L}^{-1}\right) \\
{ }^{2}\left(\log _{10} \mathrm{MPN} \cdot \mathrm{mL}^{-1}\right)\end{array}$ & $\begin{array}{c}1(\%) \\
{ }^{2}\left(\log _{10} \mathrm{MPN} \cdot \mathrm{mL}^{-1}\right)\end{array}$ \\
\hline${ }^{1} \mathrm{COD}$ & $114 \pm 29$ & $70^{\mathrm{a}} \pm 4.7$ & $48 \pm 19$ & $87^{b} \pm 2.6$ & $102 \pm 29$ & $74^{c} \pm 2.6$ \\
\hline${ }^{1} \mathrm{TOC}$ & $50 \pm 14$ & $64^{\mathrm{a}} \pm 5.0$ & $31 \pm 9.1$ & $77^{b} \pm 3.6$ & $48 \pm 14$ & $64^{\mathrm{a}} \pm 5.2$ \\
\hline${ }^{1} \mathrm{~N}_{\text {tot }}$ & $64 \pm 11$ & $7 \pm 8.8$ & $61 \pm 10$ & $14 \pm 8.1$ & $62 \pm 11$ & $12 \pm 4.0$ \\
\hline${ }^{1} \mathrm{P}_{\text {tot }}$ & $2.3 \pm 0.3$ & $10.4 \pm 7.1$ & $2.3 \pm 0.3$ & $13 \pm 9.0$ & $2.2 \pm 0.4$ & $15 \pm 8.5$ \\
\hline${ }^{2}$ E. coli & $4.13 \pm 0.35$ & $0.78^{\mathrm{a}} \pm 0.17$ & $3.96 \pm 0.43$ & $0.99^{b} \pm 0.31$ & $4.15 \pm 0.38$ & $0.84^{\mathrm{ab}} \pm 0.26$ \\
\hline${ }^{2}$ Enterococci & $3.47 \pm 0.32$ & $0.82^{\mathrm{a}} \pm 0.18$ & $3.28 \pm 0.34$ & $1.02^{b} \pm 0.3$ & $3.47 \pm 0.38$ & $0.81^{\mathrm{a}} \pm 0.28$ \\
\hline
\end{tabular}

Note: ${ }^{1} \mathrm{COD}, \mathrm{TOC}, \mathrm{N}_{\text {tot }}$ and $\mathrm{P}_{\text {tot }}$ are presented as $\mathrm{mg} \cdot \mathrm{L}^{-1}$ and percentage respectively; ${ }^{2}$ E. coli and Enterococci are presented as $\log _{10} \mathrm{MPN} \cdot \mathrm{mL}^{-1}$.

Overall, anaerobic filtration is an effective treatment of low-strength wastewater, particularly for COD removal $[7,9]$. Although the measurement of gas production in filters was not possible, a biogas production proportional to the conversion of COD is very likely $[7,41,42]$.

No statistically significant differences in removal rates of $\mathrm{N}_{\text {tot }}$ and $\mathrm{P}_{\text {tot }}$ were observed for all three filter materials. Due to the anaerobic conditions (compare Section 3.5), removal rates of $N_{\text {tot }}$ and $P_{\text {tot }}$ were very low in all nine columns. Depending on the further use of filter effluents, additional water treatment is necessary. However, for reuse as irrigation water, high effluent concentrations of nitrogen and phosphorus might be positive, reducing the fertilizer requirement $[43,44]$.

\subsection{Effect of Filter Materials on Effluent Turbidity}

Influent turbidity was unstable over the whole experiment between 60 and $360 \mathrm{FNU}$ (mean: 200 FNU, SD: 92, $n=6$ ). Over the entire experiment, biochar filters performed significantly better and more constant regarding turbidity reduction than the other two filter materials (Figure 2). Especially at the beginning of the column experiment, biochar filters showed lower effluent turbidity (Figure 2b). The performance of woodchips and gravel filters was in a comparable range for effluent turbidity (Figure 2). The average effluent turbidities of woodchips, biochar, and gravel filters were 20 FNU (SD: 6.0, $n=24$ ), 14 FNU (SD: 8.2, $n=24$ ), and 26 FNU (SD: 15.9, $n=26$ ), respectively. 
This resulted in an average turbidity reduction of $90 \%$ for woodchips, $93 \%$ for biochar, and $87 \%$ for gravel filters.

Over the entire experiment, the turbidity removal patterns of all three materials were on a constant level, with significantly higher values for biochar filters compared to other materials (woodchips: $U=437.5$, $z=3.07258, p>0.00164$; gravel: $\left.U=142.5, z=-3.28202, p>7.35 \times 10^{4}\right)$. No significant difference between woodchips and gravel could be observed $(U=262.5, z=-0.95166, p>0.34191)$.

The achieved removal rates were considerably higher [45] or in a similar range [16] to other published results. Despite being mostly unreported in anaerobic filtration studies, turbidity removal is an interesting parameter for a simple and quick estimation of suspended solids in water samples. In general, suspended solids and thus turbidity removal is higher at lower HLRs and higher hydraulic retention times [46]. Nevertheless, biochar and woodchips filters were very similar regarding porosity, HRT, and tracer-curve progression. Hence, the most likely explanation for higher turbidity removal rates of biochar filters is adsorption through its high specific surface area. Lower UV-absorbance of effluent of biochar filters supports this hypothesis (compare Section 3.6).
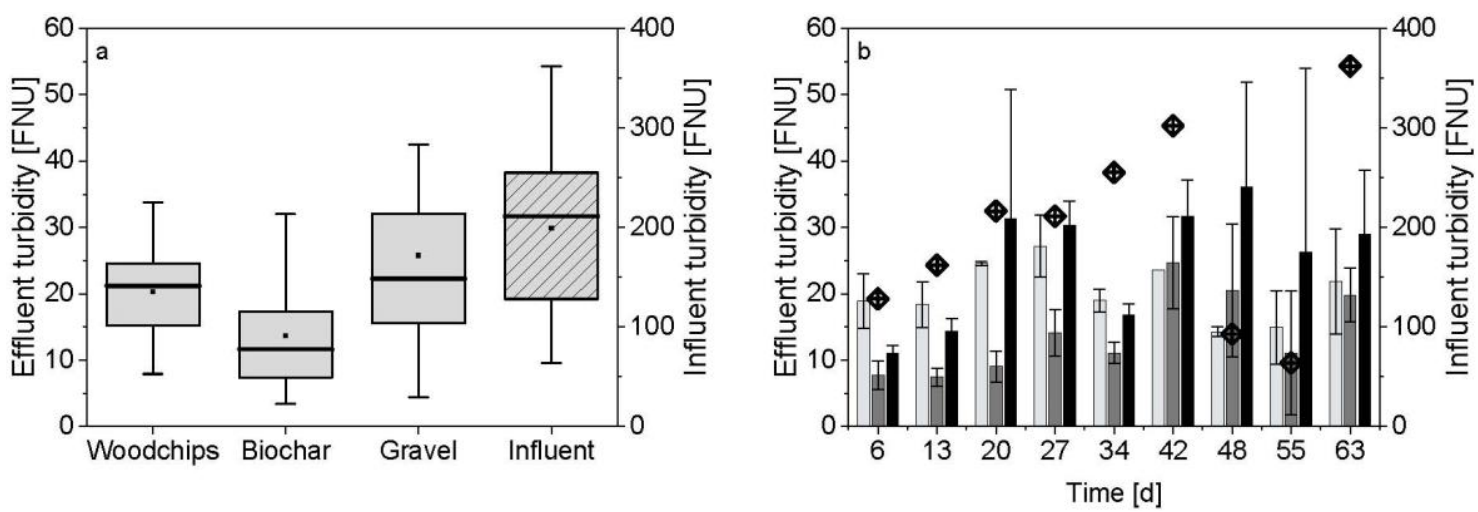

Figure 2. (a) Box-plots of the effluent and influent turbidity of different filter materials. Whiskers represent 1.5 interquartile ranges, and average values are represented as black squares. (b) Average turbidity of gravel (black), biochar (grey), and woodchips (light grey) filter effluent and influent (diamond with cross) over time. Error bars represent standard deviation.

\subsection{Effect of Filter Materials on Removal Rates of FIB}

Over the entire experiment, influent FIB concentration was in the range of 4.19 to $5.46 \log _{10} \mathrm{MPN} \cdot \mathrm{mL}^{-1}$ with an average of $4.93 \pm 0.39 \mathrm{for}$ E. coli. Enterococci concentration was between 3.90 to $4.73 \log _{10} \mathrm{MPN} \cdot \mathrm{mL}^{-1}$ with an average of $4.29 \pm 0.28$. The mean reduction of FIB over experimental time was between 0.78 and $1.02 \log _{10}$-units, and is summarized in Table 3. Maximum reduction was $1.7 \log _{10}$-units. Compared to other filter materials, biochar columns removed significantly (ANOVA, $p<0.05$ ) more E. coli (ANOVA, $p<0.05$ ) and enterococci than woodchip filters, and significantly more enterococci than gravel filters. No significant differences in removal rates of $E$. coli could be observed for biochar and gravel filters and of FIB between gravel and woodchips (Table 3). Thereby, removal patterns were comparable for E. coli and enterococci. A correlation between influent concentration of FIB and removal rates could not be determined. However, a significant reduction of pathogens during filtration could be observed.

Removal rates of FIB which were achieved in this experiment were in line with other published results $[13,14,47]$ or higher $[45,48]$. Overall, the reduction of FIB (Table 3) was too low to allow direct water reuse for irrigation, and further treatment is necessary to fulfil WHO guidelines for unrestricted irrigation [49]. Thus, sand filters or biofilters [15,50-52], biochar augmented filters [28,53], or zero-valent-iron amended filters [54] are reliable low-cost alternatives for post-treatment. Due to the very low effluent turbidity and COD concentration, AF is ideally suited for pre-treatment for such simple disinfection methods. The low effluent turbidity of AF may also allow a further inactivation of 
FIB in treated water by solar radiation, which is higher at lower turbidity levels $[55,56]$. Since turbidity reduction was most efficient through biochar filtration, this may result in a higher inactivation of FIB in the effluent of biochar filters compared to gravel and woodchip filters.

\subsection{Effect of Different Filter Materials on Physical Parameters}

During the column experiment, the physical parameters $\mathrm{pH}, \mathrm{EC}$, and temperature were measured weekly. The results are summarized in Table S4. The redox potential, which was measured randomly in influent and effluent, was always below $-300 \mathrm{mV}$, and indicated strict anaerobic conditions. Over the whole experiment, no significant difference (ANOVA, $p<0.05$ ) could be found for EC between filter influent and effluent of all materials, and mean EC was in the range of $1150-1180 \mu \mathrm{S} / \mathrm{cm}$. The gravel filter showed slightly higher $\mathrm{pH}$ values than the influent and the other filter materials. Measured $\mathrm{pH}$ of influent and effluent was between 7.3 and 8.3. Due to controlled and stable environment conditions, temperature influences (constantly at $22{ }^{\circ} \mathrm{C}$ ) on removal rates in different filters can be excluded.

\subsection{UV Absorbance of Filter Effluents and Raw Water}

UV absorbance was measured between $190 \mathrm{~nm}$ and $254 \mathrm{~nm}$. While mean absorbance at $254 \mathrm{~nm}$ $\left(\mathrm{UVA}_{254}\right)$ of woodchip $\left(\mathrm{UVA}_{254}=0.34 \mathrm{~cm}^{-1}\right.$, SD: $\left.0.033, n=16\right)$ and gravel $\left(\mathrm{UVA}_{254}=0.295 \mathrm{~cm}^{-1}\right.$, SD: $0.064, n=16)$ filter effluent was in the range of influent ( $\mathrm{UVA}_{254}=0.352 \mathrm{~cm}^{-1}$, SD: $\left.0.09, n=6\right)$, biochar filters $\left(\mathrm{UVA}_{254}=0.074 \mathrm{~cm}^{-1}\right.$, SD: $\left.0.033, n=16\right)$ showed a significantly lower extinction (ANOVA, $p<0.05$ ) (Figure 3). Since $\mathrm{UVA}_{254}$ is a common parameter to measure natural organic matter (NOM), which is expected to be removed mainly by adsorption on filter material [57], this outcome indicates a higher adsorption capacity of biochar. Over the experimental time, no clear trend could be identified for $\mathrm{UVA}_{254}$ for woodchip and gravel filters, while absorbance of biochar effluent showed a slight increase over time (Figure 3). This slight increase of biochar effluent might be explained by the saturation of the biochar adsorption capacity. Aside from the first sampling, the $\mathrm{UVA}_{254}$ of gravel filters was slightly lower than woodchips. The large difference between these two materials at the first sampling might be explained by the release of organic substances from woodchips [22,38], because the $\mathrm{UVA}_{254}$ of effluent of woodchip filters were even higher than the UV absorbance of raw water. Similar results for both materials regarding COD, TOC, and turbidity removal, and the slightly higher $\mathrm{UVA}_{254}$ of woodchip columns over the entire experiment supports this hypothesis. Results for UVA 201 are shown in Figure S2. Correlation analysis between COD concentration and UV absorbance at 201 $\mathrm{nm}\left(\mathrm{R}^{2}=0.826\right)$ and $254 \mathrm{~nm}\left(\mathrm{R}^{2}=0.767\right)$ indicates a clear correlation between these two parameters (Figure 3). These results were in contrast with the studies of Hur and Cho [58], who found a weaker correlation at a wavelength of $220 \mathrm{~nm}$.

Overall, the calculated correlation coefficients between both parameters were clearly lower than in other studies [58,59]. Thus, UV absorbance measurements could potentially be implemented as a simple and cheap tool for monitoring the adsorption capacity and COD removal efficiency of AF, indicating malfunctions and overloads. Such a low-cost and simple analytical tool is especially relevant for the implementation of the technology in low-income countries, but further research is necessary to validate these results under other operational conditions. 

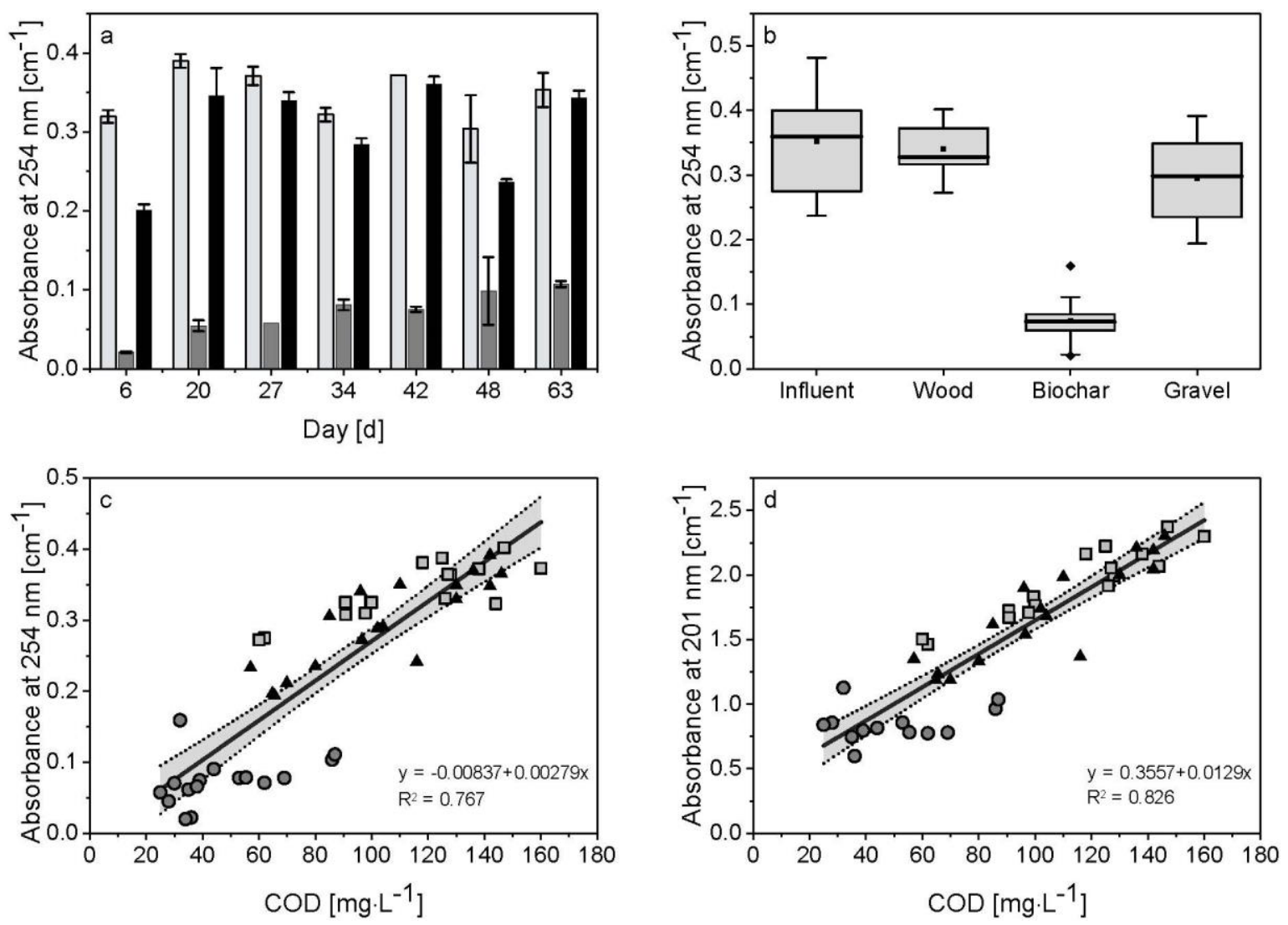

Figure 3. (a) Mean UV extinction of filter effluents at $254 \mathrm{~nm}$ of gravel (black), biochar (grey), and woodchips (light grey) over time. Error bars represent standard deviation. (b) Boxplot of UV absorbance at $254 \mathrm{~nm}$ of filter effluent and raw water. Correlation between COD concentration and UV absorbance at (c) $201 \mathrm{~nm}$ and (d) $254 \mathrm{~nm}$ of filter effluent of gravel (black triangles), biochar (grey circles), and woodchips (light grey squares) filters. Straight lines are regression lines with $95 \%$ confidence zones (grey area between dotted lines).

\subsection{Evaluation of Filter Materials and Treatment Efficiency}

The achieved COD and FIB removal efficiencies of AF in this experiment were on the same order of magnitude as other potential treatment systems for developing countries, such as different pond systems or trickling filters [11]. Presuming an average daily wastewater quantity of $120 \mathrm{~L}$ per capita and day, the required land use of AF with a primary sedimentation and relevant infrastructure would be less than $0.2 \mathrm{~m}^{2}$ per capita, and thus four times lower than rapid infiltration and approximately 15 times lower than constructed wetlands [11]. In an ongoing long-term experiment treating wastewater with a similar AF (data not shown), achieved effluent water quality is constant and equal to the presented study, and filters need to be backflushed only every 6 to 8 months. Consequently, AF is a highly suitable and robust treatment system for wastewater treatment in developing countries.

Over the entire experiment, the removal efficiency of biochar filters was superior or equal for the investigated parameters compared to gravel or woodchips. Due to the high adsorption capacity, biochar is also potentially able to remove organic and inorganic substances (e.g., pharmaceutical products, pesticides, phenols, and heavy metals) [24,29] from wastewater, and may thus contribute to a safer environment and improved water quality. Hence, biochar filters might also be a potential treatment system for wastewater disposal and water supply during extreme weather events $[60,61]$. Due to the possibility of bioregeneration of the biochar material [62], the adsorption capacity of biochar filters can be prolonged, and thus higher removal rates might also be achieved in long-term experiments. 


\section{Conclusions}

The anaerobic filtration of municipal wastewater is a highly suitable and low-cost technology for the removal of COD, TOC, and turbidity, particularly for low-income countries where appropriate wastewater treatment is often lacking. AFs are also able to remove a substantial amount of FIB from raw wastewater. The materials considered in this study showed good suitability as filter materials for anaerobic wastewater filtration, and the effluent of all filters is expected to be suitable for disinfection with various post treatments. Since no start-up phase was necessary to achieve constant removal rates, AF has an enormous potential as a wastewater treatment method for emergency situations (e.g., earthquakes, floods, or refugee camps). Over the entire experiment, the performance of biochar filters was superior or equal to woodchips and gravel filters for the investigated parameters. Hence, biochar is expected to be a highly suitable and sustainable material for anaerobic wastewater filtration-particularly due to the possibility that biochar can be produced locally from organic waste products or agricultural residues. Due to the low effluent turbidity of AF, further studies should also include the effects of wastewater treatment on the survival rates of FIB in receiving water bodies. Additionally, the influence of low UV absorbance in treated wastewater on the behaviour of hazardous substances in surface water should be investigated.

Supplementary Materials: The following are available online at http://www.mdpi.com/2073-4441/10/7/818/s1. Figure S1: Electrical conductivity over time of effluents from different filter units after adding a pulse of $\mathrm{NaCl}$ to influent tab water, Figure S2: Mean UV-Extinction of filter effluents at $201 \mathrm{~nm}$ (a) of gravel (black), biochar (grey) and woodchips (light grey) over time, Figure S3: Samples of filter influent (right) and effluent of biochar filter (left), Table S1: Chemical and physical characteristics of biochar and woodchips, Table S2: Chemical and physical characteristics of quartz gravel, Table S3: Porosity of different filter materials and theoretical hydraulic retention time, Table S4: Physical parameters of filter influent and effluent.

Author Contributions: K.K. conceived and designed the experiments. M.L., T.G. and M.W. contributed to the conception and design of the study. K.K. performed the experiments and analysed the data. All authors contributed to the overall framing and revision of the manuscript at multiple stages.

Acknowledgments: This study was carried out within the framework of the UrbanFoodPlus Project under the GlobE-Research initiative for Global Food Supply (FKZ: 031A242-B), jointly funded by the German Federal Ministry of Education and Research (BMBF) and the Federal Ministry for Economic Cooperation and Development (BMZ). We are grateful to Ilka Papajewski, Mike im Spring and Karsten Alfes for their assistance during the experiment and Christoph Steiner for coordinating the UrbanFoodPlus Project. We thank the anonymous reviewers for their valuable comments and Marc Hansen for proof-reading the manuscript. We acknowledge support by the German Research Foundation (DFG) and the Open Access Publication Funds of the Ruhr-Universität Bochum.

Conflicts of Interest: The authors declare no conflict of interests. 


\section{Appendix A}

Table A1. Literature review of anaerobic filter (AF) and anaerobic biofilter (AnBF) for wastewater treatment.

\begin{tabular}{|c|c|c|c|c|c|c|c|c|}
\hline & & & Temperature & Influent & OLR & HRT & Efficiency & \\
\hline Raw water & Filter material & Filter Type & $\left({ }^{\circ} \mathrm{C}\right)$ & $\begin{array}{l}\left(\mathrm{mg}_{\mathrm{COD}} \cdot \mathrm{L}^{-1}\right) \\
*\left(\mathrm{mg}_{\mathrm{BOD}} \cdot \mathrm{L}^{-1}\right)\end{array}$ & $\begin{array}{c}\left(\mathrm{kg}_{\mathrm{COD}} \cdot \mathrm{m}^{-3} \cdot \mathrm{d}^{-1}\right) \\
*\left(\mathrm{~kg}_{\text {вOD }} \cdot \mathrm{m}^{-3} \cdot \mathrm{d}^{-1}\right)\end{array}$ & (h) & $\begin{array}{l}\text { COD (\%) } \\
{ }^{*} \text { BOD }(\%)\end{array}$ & Reference \\
\hline DWW & Tezontle & $\mathrm{AF}$ & $23.2 \pm 1.9$ & $436 \pm 72$ & $0.298 \pm 0.049^{a}$ & 18 & 76.1 & [63] \\
\hline DWW & Baked clay & septic tank + AF & $12-40$ & $411 \pm 156$ & $0.13-1.09$ & $18.1-19.7$ & $88.6 \pm 3.7$ & [13] \\
\hline DWW & Coconut shell & $\mathrm{AF}$ & $24.5 \pm 5.4$ & $982 \pm 424$ & NA & 9 & $65 \pm 15$ & [15] \\
\hline DWW & Reticulated polyurethane foam & $\mathrm{AF}$ & 13 & $518 \pm 222$ & NA & 4 & $55 \pm 8$ & [42] \\
\hline DWW & Reticulated polyurethane foam & $\mathrm{AF}$ & 13 & $461 \pm 134$ & NA & 4 & $>40$ & [64] \\
\hline DWW + SS & Plastic rings & $\mathrm{AF}$ & 24 & $\begin{array}{l}450 \\
575 \\
780\end{array}$ & NA & $\begin{array}{c}6 \\
10 \\
20\end{array}$ & $\begin{array}{l}77 \\
92 \\
90\end{array}$ & [9] \\
\hline DWW + SS & Plastic material & $\mathrm{AF}$ & 23 & 780 & 0.75 & $24^{\mathrm{b}}$ & 90 & [10] \\
\hline DWW & Sand & $\mathrm{AnBF}$ & $20 \pm 1$ & $305 \pm 90^{\mathrm{a}}$ & $0.204-0.36^{\mathrm{a}}$ & $12-26$ & 58 & [25] \\
\hline DWW & Miscanthus Biochar & $\mathrm{AnBF}$ & $20 \pm 1$ & $305 \pm 90^{\mathrm{a}}$ & $0.204-0.36^{a}$ & $15-29$ & 73 & [25] \\
\hline DWW & Coconut shell & $\mathrm{AF}$ & $25.4 \pm 4.5$ & $1105 \pm 338$ & NA & 9 & $73 \pm 12$ & [12] \\
\hline DWW & Bamboo rings & $\mathrm{AF}$ & NA & 996 & NA & 9 & $60-80$ & [18] \\
\hline DWW & Rock & $\mathrm{AF}$ & $23-27$ & $94^{*}$ & $0.05 *$ & 15 & $82-83^{*}$ & [20] \\
\hline DWW & Wood slats & $\mathrm{AF}$ & $23-27$ & $106^{*}$ & 0.08 & 18 & $78 *$ & [20] \\
\hline DWW & Wood slats & $\mathrm{AF}$ & $23-27$ & $84 *$ & $0.05^{*}$ & 22 & $83 *$ & [20] \\
\hline DWW & Cylindrical plastic rings & $\mathrm{AF}$ & $17-28$ & $260-540$ & 0.965 & $10^{\mathrm{b}}$ & 75.9 & [65] \\
\hline DWW & $\begin{array}{l}\text { Ceramic saddles } \\
\text { Crashed stone }\end{array}$ & $\mathrm{AF}$ & 25.2 & 434 & 0.434 & $\begin{array}{l}14.2 \\
16.1 \\
\end{array}$ & $\begin{array}{l}70.5 \\
67.9 \\
\end{array}$ & [66] \\
\hline LSDWW & Waste tyre rubber & $\mathrm{AF}$ & $30-35$ & $941 \pm 67$ & NA & 24 & 60 & [67] \\
\hline \multirow[t]{2}{*}{ SS } & \multirow[t]{2}{*}{ Quartzite stones } & \multirow[t]{2}{*}{$\mathrm{AF}$} & \multirow[t]{2}{*}{25} & 1500 & $\begin{array}{l}3.392^{a}, 1.696^{a}, \\
0.858^{a}, 0.425^{a}\end{array}$ & $4.5,9,18,36$ & $36.7,79.3,91.5,92.1$ & \multirow[t]{2}{*}{ [7] } \\
\hline & & & & 3000 & $3.392^{a}, 0.858^{a}, 0.425^{a}$ & $9,36,72$ & $63,88.4,93.4$ & \\
\hline AWW & Vinylidene chloride & $\mathrm{AF}$ & $\begin{array}{l}20 \\
30\end{array}$ & $200^{*}$ & $0.64^{a *}, 0.32^{a *}, 0.16^{a *}$ & $7.5,15,30$ & $\begin{array}{c}36^{*}, 66^{*}, 86^{*} \\
87.5^{*}, 93^{*}, 95^{*}\end{array}$ & [68] \\
\hline
\end{tabular}


Table A1. Cont.

\begin{tabular}{|c|c|c|c|c|c|c|c|c|}
\hline & & & Temperature & Influent & OLR & HRT & Efficiency & \\
\hline Raw water & Filter material & Filter Type & $\left({ }^{\circ} \mathrm{C}\right)$ & $\begin{array}{l}\left(\mathrm{mg}_{\mathrm{COD}} \cdot \mathrm{L}^{-1}\right) \\
*\left(\mathrm{mg}_{\mathrm{BOD}} \cdot \mathrm{L}^{-1}\right)\end{array}$ & $\begin{array}{r}\left(\mathrm{kg}_{\mathrm{COD}} \cdot \mathrm{m}^{-3} \cdot \mathrm{d}^{-1}\right) \\
{ }^{*}\left(\mathrm{~kg}_{\mathrm{BOD}} \cdot \mathrm{m}^{-3} \cdot \mathrm{d}^{-1}\right)\end{array}$ & (h) & $\begin{array}{l}\text { COD (\%) } \\
* \text { BOD (\%) }\end{array}$ & Reference \\
\hline AWW & $\mathrm{PVC}^{\mathrm{e}}$ pall rings & $\mathrm{AF}$ & 35 & 2500 & 2 & $30^{\mathrm{b}}$ & $95-96$ & [69] \\
\hline LSDWW & Non-woven fabric material & $\begin{array}{l}\text { Three AF + } \\
\text { AnOx }{ }^{c}+\mathrm{Ox}^{\mathrm{d}} \\
\text { in series }\end{array}$ & $18-24$ & $\begin{array}{c}\text { 131-398 } \\
\text { (mean: 210) }\end{array}$ & $0.19,0.11,0.07$ & $24,48,72$ & $32,40,44$ & {$[70]$} \\
\hline LSDWW & $\mathrm{PVC}^{\mathrm{e}}$ packing material & $\mathrm{AF}$ & $18-35$ & $\begin{array}{l}\text { 77-1170 } \\
\text { (mean: 288) }\end{array}$ & $\begin{array}{l}0.07^{\mathrm{a}}-1.08^{\mathrm{a}} \\
\left(\text { mean: } 0.266^{\mathrm{a}}\right)\end{array}$ & 24 & 73 & [45] \\
\hline $\begin{array}{c}\text { Effluent of septic } \\
\text { tank }\end{array}$ & Plastic ballast rings & $\mathrm{AF}$ & 20 & $\begin{array}{c}130-580 \\
\text { (mean: } 293 \pm \\
104)\end{array}$ & NA & 29 & 49 & [14] \\
\hline Greywater & PVC $^{\mathrm{e}}$ packing material & $\mathrm{AF}$ & $20-28$ & $170 \pm 100$ & $0.34^{\mathrm{a}}$ & NA & 72 & [16] \\
\hline
\end{tabular}

DWW = domestic wastewater; LSDWW = low-strength domestic wastewater; AWW = artificial wastewater; SS
${ }^{c} \mathrm{AnOx}=$ Anoxic filter; ${ }^{\mathrm{d}} \mathrm{Ox}=$ Oxic filter; ${ }^{\mathrm{e}} \mathrm{PVC}=$ polyvinyl chloride; ${ }^{*}$ numbers are given as BOD instead of COD. 


\section{References}

1. Shannon, M.A.; Bohn, P.W.; Elimelech, M.; Georgiadis, J.G.; Marĩas, B.J.; Mayes, A.M. Science and technology for water purification in the coming decades. Nature 2008, 452, 301-310. [CrossRef] [PubMed]

2. Schlosser, C.; Strzepek, K.; Gao, X. The Future of Global Water Stress: An Integrated Assessment. Earth's Future 2014, 2, 341-361. [CrossRef]

3. Cohen, B. Urban growth in developing countries: A review of current trends and a caution regarding existing forecasts. World Dev. 2004, 32, 23-51. [CrossRef]

4. WWAP (United Nations World Water Assessment Programme). The United Nations World Water Development Report 2017. Wastewater: The Untapped Resource; Unesco Publishing: Paris, France, 2017; ISBN 9789231002014.

5. Sato, T.; Qadir, M.; Yamamoto, S.; Endo, T.; Zahoor, A. Global, regional, and country level need for data on wastewater generation, treatment, and use. Agric. Water Manag. 2013, 130, 1-13. [CrossRef]

6. Steduto, P.; Faurès, J.-M.; Hoogeveen, J.; Winpenny, J.; Burke, J. Coping with Water Scarcity: An Action Framework for Agriculture and Food Security; Food and Agriculture Organization of the United Nations: Rome, Italy, 2012.

7. Young, J.C.; McCarty, P.L. The anaerobic filter for waste treatment. J. Water Pollut. Control Fed. 1969, 41. [CrossRef]

8. Young, J.C. Factors affecting the design and performance of upflow anaerobic filters. Water Sci. Technol. 1991, 24, 133-155. [CrossRef]

9. Bodík, I.; Herdová, B.; Drtil, M. The use of upflow anaerobic filter and AnSBR for wastewater treatment at ambient temperature. Water Res. 2002, 36, 1084-1088. [CrossRef]

10. Bodik, I.; Herdova, B.; Kratochvil, K. The application of anaerobic filter for municipal wastewater treatment. Chem. Pap. Acad. Sci. 2000, 54, 159-164.

11. Sperling, M.; Von de Lemos Chernicharo, C.A. Biological Wastewater Treatment in Warm Climate Regions_Volume I; IWA Publishing: London, UK, 2005; ISBN 1843390027.

12. De Oliveira Cruz, L.M.; Stefanutti, R.; Filho, B.C.; Tonetti, A.L. Coconut shells as filling material for anaerobic filters. Springerplus 2013, 2,1-6. [CrossRef]

13. Sharma, M.K.; Khursheed, A.; Kazmi, A.A. Modified septic tank-anaerobic filter unit as a two-stage onsite domestic wastewater treatment system. Environ. Technol. 2014, 35, 2183-2193. [CrossRef] [PubMed]

14. Viraraghavan, T.; Dickenson, K. Low-temperature anaerobic filtration of septic tank effluent. Cold Reg. Sci. Technol. 1991, 19, 245-252. [CrossRef]

15. Tonon, D.; Tonetti, A.L.; Coraucci Filho, B.; Bueno, D.A.C. Wastewater treatment by anaerobic filter and sand filter: Hydraulic loading rates for removing organic matter, phosphorus, pathogens and nitrogen in tropical countries. Ecol. Eng. 2015, 82, 583-589. [CrossRef]

16. Do Couto, E.D.A.; Calijuri, M.L.; Assemany, P.P.; Santiago, A.D.F.; Lopes, L.S. Greywater treatment in airports using anaerobic filter followed by UV disinfection: An efficient and low cost alternative. J. Clean. Prod. 2015, 106, 372-379. [CrossRef]

17. Frankin, R.J. Full-scale experiences with anaerobic treatment of industrial wastewater. Water Sci. Technol. 2001, 44, 1-6. [CrossRef] [PubMed]

18. Camargo, S.A.R.; Nour, E.A.A. Bamboo as an anaerobic medium: Effect of filter column height. Water Sci. Technol. 2001, 44, 63-70. [CrossRef] [PubMed]

19. Vigueras-Cortés, J.M.; Villanueva-Fierro, I.; Garzón-Zúñiga, M.A.; de Jesús Návar-Cháidez, J.; Chaires-Hernández, I.; Hernández-Rodríguez, C. Performance of a biofilter system with agave fiber filter media for municipal wastewater treatment. Water Sci. Technol. 2013, 68, 599-607. [CrossRef] [PubMed]

20. Viraraghavan, T.; Landine, R.C.; Pyke, S.R. Anaerobic Filters for Municipal Wastewater Treatment. J. Chem. Biotechnol. 1989, 46, 71-76. [CrossRef]

21. Garzón-Zúñiga, M.A.; Buelna, G. Treatment of wastewater from a school in a decentralized filtration system by percolation over organic packing media. Water Sci. Technol. 2011, 64, 1169. [CrossRef] [PubMed]

22. Sosa-Hernández, D.B.; Vigueras-Cortés, J.M.; Garzón-Zúñiga, M.A. Mesquite wood chips (Prosopis) as filter media in a biofilter system for municipal wastewater treatment. Water Sci. Technol. 2016, 73, 1454-1462. [CrossRef] [PubMed]

23. Ahsan, S.; Kaneco, S.; Ohta, K.; Mizuno, T.; Kani, K. Use of some natural and waste materials for waste water treatment. Water Res. 2001, 35, 3738-3742. [CrossRef] 
24. Dalahmeh, S.; Ahrens, L.; Gros, M.; Wiberg, K.; Pell, M. Potential of biochar filters for onsite sewage treatment: Adsorption and biological degradation of pharmaceuticals in laboratory filters with active, inactive and no biofilm. Sci. Total Environ. 2018, 612, 192-201. [CrossRef] [PubMed]

25. Kätzl, K.; Lübken, M.; Alfes, K.; Werner, S.; Marschner, B.; Wichern, M. Slow sand and slow biochar filtration of raw wastewater. In Progress in Slow Sand and Alternative Biofiltration Processes: Further Developments and Applications; Nakamoto, N., Graham, N., Collins, M.R., Gimbel, R., Eds.; IWA Publishing: London, UK, 2014; pp. 297-305. ISBN 9781780406374.

26. Zhou, X.; Liang, C.; Jia, L.; Feng, L.; Wang, R.; Wu, H. An innovative biochar-amended substrate vertical flow constructed wetland for low $\mathrm{C} / \mathrm{N}$ wastewater treatment: Impact of influent strengths. Bioresour. Technol. 2018, 247, 844-850. [CrossRef]

27. Kizito, S.; Tao, L.; Wu, S.; Ajmal, Z.; Luo, H.; Dong, R. Treatment of anaerobic digested effluent in biochar-packed vertical flow constructed wetland columns: Role of media and tidal operation. Sci. Total Environ. 2017, 592, 197-205. [CrossRef] [PubMed]

28. Mohanty, S.K.; Cantrell, K.B.; Nelson, K.L.; Boehm, A.B. Efficacy of biochar to remove Escherichia coli from stormwater under steady and intermittent flow. Water Res. 2014, 61, 288-296. [CrossRef] [PubMed]

29. Mohan, D.; Sarswat, A.; Ok, Y.S.; Pittman, C.U. Organic and inorganic contaminants removal from water with biochar, a renewable, low cost and sustainable adsorbent-A critical review. Bioresour. Technol. 2014, 160, 191-202. [CrossRef] [PubMed]

30. Li, H.; Dong, X.; da Silva, E.B.; de Oliveira, L.M.; Chen, Y.; Ma, L.Q. Mechanisms of metal sorption by biochars: Biochar characteristics and modifications. Chemosphere 2017, 178, 466-478. [CrossRef] [PubMed]

31. Peters, J.; Iribarren, D.; Dufour, J. Biomass pyrolysis for biochar or energy applications? A life cycle assessment. Environ. Sci. Technol. 2015, 49, 5195-5202. [CrossRef] [PubMed]

32. Gwenzi, W.; Chaukura, N.; Noubactep, C.; Mukome, F.N.D. Biochar-based water treatment systems as a potential low-cost and sustainable technology for clean water provision. J. Environ. Manag. 2017, 197, 732-749. [CrossRef] [PubMed]

33. Steiner, C.; Bellwood-Howard, I.; Häring, V.; Tonkudor, K.; Addai, F.; Atiah, K.; Abubakari, A.H.; Kranjac-Berisavljevic, G.; Marschner, B.; Buerkert, A. Participatory trials of on-farm biochar production and use in Tamale, Ghana. Agron. Sustain. Dev. 2018, 38, 12. [CrossRef]

34. Werner, S.; Kätzl, K.; Wichern, M.; Buerkert, A.; Steiner, C.; Marschner, B. Agronomic benefits of biochar as a soil amendment after its use as waste water filtration medium. Environ. Pollut. 2018, 233, 561-568. [CrossRef] [PubMed]

35. Ahmad, M.; Lee, S.S.; Dou, X.; Mohan, D.; Sung, J.K.; Yang, J.E.; Ok, Y.S. Effects of pyrolysis temperature on soybean stover- and peanut shell-derived biochar properties and TCE adsorption in water. Bioresour. Technol. 2012, 118, 536-544. [CrossRef] [PubMed]

36. Mukherjee, A.; Zimmerman, A.R.; Harris, W. Surface chemistry variations among a series of laboratory-produced biochars. Geoderma 2011, 163, 247-255. [CrossRef]

37. Wichern, M.; Lindenblatt, C.; Lübken, M.; Horn, H. Experimental results and mathematical modelling of an autotrophic and heterotrophic biofilm in a sand filter treating landfill leachate and municipal wastewater. Water Res. 2008, 42, 3899-3909. [CrossRef] [PubMed]

38. Lens, P.N.; Vochten, P.M.; Speleers, L.; Verstraete, W.H. Direct treatment of domestic wastewater by percolation over peat, bark and woodchips. Water Res. 1994, 28, 17-26. [CrossRef]

39. Dalahmeh, S.S.; Pell, M.; Vinnerås, B.; Hylander, L.D.; Öborn, I.; Jönsson, H. Efficiency of Bark, Activated Charcoal, Foam and Sand Filters in Reducing Pollutants from Greywater. Water Air Soil Pollut. 2012, 223, 3657-3671. [CrossRef]

40. Lübken, M.; Wichern, M.; Bischof, F.; Prechtl, S.; Horn, H. Development of an empirical mathematical model for describing and optimizing the hygiene potential of a thermophilic anaerobic bioreactor treating faeces. Water Sci. Technol. 2007, 55, 95-102. [CrossRef] [PubMed]

41. Ruiz, I.; Veiga, M.C.; De Santiago, P.; Blázquez, R. Treatment of slaughterhouse wastewater in a UASB reactor and an anaerobic filter. Bioresour. Technol. 1997, 60, 251-258. [CrossRef]

42. Elmitwalli, T.A.; Sklyar, V.; Zeeman, G.; Lettinga, G. Low temperature pre-treatment of domestic sewage in an anaerobic hybrid or an anaerobic filter reactor. Bioresour. Technol. 2002, 82, 233-239. [CrossRef]

43. McCarty, P.L. What is the Best Biological Process for Nitrogen Removal-When and Why? Environ. Sci. Technol. 2018, 52, 3835-3841. [CrossRef] [PubMed] 
44. Angelakis, A.; Snyder, S. Wastewater Treatment and Reuse: Past, Present, and Future. Water 2015, 7, 4887-4895. [CrossRef]

45. Kobayashi, H.A.; Stenstrom, M.K.; Mah, R.A. Treatment of low strength domestic wastewater using the anaerobic filter. Water Res. 1983, 17, 903-909. [CrossRef]

46. Smet, J.E.M.; Visscher, J.T. Pre-Treatment Methods for Community Water Supply: An Overview of Techniques and Present Experience; IRC International Water and Sanitation Centre: The Hage, The Netherlands, 1989.

47. Oakley, S.; von Sperling, M. Media Filters: Trickling Filters and Anaerobic Filters. In Global Water Pathogens Project; Part 4 Management of Risk from Excreta and Wastewater; Haas, C., Mihelcic, J., Verbyla, M., Eds.; Michigan State University: E. Lansing, MI, UNESCO, 2017.

48. Polprasert, C.; Hoang, L.H. Kinetics of bacteria and bacteriophages in anaerobic filters. Water Environ. Fed. 1983, 55, 385-391.

49. WHO. Guidelines for the Safe Use of Wastewater, Excreta and Greywater, Volume 2: Wastewater Use in Agriculture; World Health Organization: Geneve, Italy, 2006; Volume II.

50. Kauppinen, A.; Martikainen, K.; Matikka, V.; Veijalainen, A.M.; Pitkänen, T.; Heinonen-Tanski, H.; Miettinen, I.T. Sand filters for removal of microbes and nutrients from wastewater during a one-year pilot study in a cold temperate climate. J. Environ. Manag. 2014, 133, 206-213. [CrossRef] [PubMed]

51. Young-Rojanschi, C.; Madramootoo, C. Intermittent versus continuous operation of biosand filters. Water Res. 2014, 49, 1-10. [CrossRef] [PubMed]

52. Langenbach, K.; Kuschk, P.; Horn, H.; Kästner, M. Slow sand filtration of secondary clarifier effluent for wastewater reuse. Environ. Sci. Technol. 2009, 43, 5896-5901. [CrossRef] [PubMed]

53. Ulrich, B.A.; Loehnert, M.; Higgins, C.P. Improved contaminant removal in vegetated stormwater biofilters amended with biochar. Environ. Sci. Water Res. Technol. 2017, 3, 726-734. [CrossRef]

54. Tepong-Tsindé, R.; Crane, R.; Noubactep, C.; Nassi, A.; Ruppert, H. Testing Metallic Iron Filtration Systems for Decentralized Water Treatment at Pilot Scale. Water 2015, 7, 868-897. [CrossRef]

55. Castro-Alférez, M.; Inmaculada Polo-López, M.; Marugán, J.; Fernández-Ibáñez, P. Validation of a solar-thermal water disinfection model for Escherichia coli inactivation in pilot scale solar reactors and real conditions. Chem. Eng. J. 2018, 331, 831-840. [CrossRef]

56. Wu, X.; Feng, Z.; Yuan, B.; Zhou, Z.; Li, F.; Sun, W. Effects of solution chemistry on the sunlight inactivation of particles-associated viruses MS2. Colloids Surf. B Biointerfaces 2018, 162, 179-185. [CrossRef] [PubMed]

57. Collins, M.R.; Eighmy, T.T.; Fenstermacher, J.M., Jr.; Spanos, S.K. Removing natural organic matter by conventional slow sand filtration. J. Am. Water Works Assoc. 1992, 84, 80-90. [CrossRef]

58. Hur, J.; Cho, J. Prediction of BOD, COD, and Total Nitrogen Concentrations in a Typical Urban River Using a Fluorescence Excitation-Emission Matrix with PARAFAC and UV Absorption Indices. Sensors 2012, 12, 972-986. [CrossRef] [PubMed]

59. Bari, A.; Farooq, S. Measuring of wastewater treatment efficiency by fluorescence and UV absorbance. Environ. Monit. Assess. 1985, 5, 423-434. [CrossRef] [PubMed]

60. Fenner, R.A.; Guthrie, P.M.; Piano, E. Process selection for sanitation systems and wastewater treatment in refugee camps during disaster-relief situations. Water Environ. J. 2007, 21, 252-264. [CrossRef]

61. Khan, S.J.; Deere, D.; Leusch, F.D.L.; Humpage, A.; Jenkins, M.; Cunliffe, D.; Fitzgerald, S.K.; Stanford, B.D. Lessons and guidance for the management of safe drinking water during extreme weather events. Environ. Sci. Water Res. Technol. 2017, 3, 262-277. [CrossRef]

62. Aktas, Ö.; Cecen, F. Bioregeneration of activated carbon: A review. Int. Biodeterior. Biodegrad. 2007, 59, 257-272. [CrossRef]

63. Merino-Solís, M.; Villegas, E.; de Anda, J.; López-López, A. The Effect of the Hydraulic Retention Time on the Performance of an Ecological Wastewater Treatment System: An Anaerobic Filter with a Constructed Wetland. Water 2015, 7, 1149-1163. [CrossRef]

64. Elmitwalli, T.A.; Oahn, K.L.T.; Zeeman, G.; Lettinga, G. Treatment of domestic sewage in a two-step anaerobic filter/anaerobic hybrid system at low temperature. Water Res. 2002, 36, 2225-2232. [CrossRef]

65. Wilson, F.; Yu, H.; Tay, J.-H.; Gu, G. An empirical model for predicting the organic concentration of anaerobic filter effluents. Water Environ. Res. 1998, 70, 299-305. [CrossRef]

66. Manariotis, L.D.; Grigoropoulos, S.G. Municipal-wastewater treatment using upflow-anaerobic filters. Water Environ. Res. 2006, 78, 233-242. [CrossRef] [PubMed] 
67. Reyes, O.; Sánchez, E.; Rovirosa, N.; Borja, R.; Cruz, M.; Colmenarejo, M.F.; Escobedo, R.; Ruiz, M.; Rodríguez, X.; Correa, O. Low-strength wastewater treatment by a multistage anaerobic filter packed with waste tyre rubber. Bioresour. Technol. 1999, 70, 55-60. [CrossRef]

68. Matsushige, K.; Inamori, Y.; Mizuochi, M.; Hosomi, M.; Sudo, R. The effects of temperature on anaerobic filter treatment for low-strength organic wastewater. Environ. Technol. 1990, 11, 899-910. [CrossRef]

69. Tay, J.-H.; Show, K.; Jayaseelan, S. Effects of Media Characteristics on Performance of Upflow Anaerobic Packed-Bed Reactors. J. Environ. Eng. 1996, 122, 469-476. [CrossRef]

70. Ladu, J.L.C.; Lü, X. Effects of hydraulic retention time, temperature, and effluent recycling on efficiency of anaerobic filter in treating rural domestic wastewater. Water Sci. Eng. 2014, 7, 168-182. [CrossRef]

2018 by the authors. Licensee MDPI, Basel, Switzerland. This article is an open access article distributed under the terms and conditions of the Creative Commons Attribution (CC BY) license (http://creativecommons.org/licenses/by/4.0/). 